\title{
Exploiting thermally-reversible covalent bonds for the controlled release of microencapsulated isocyanate crosslinkers
}

Article

Accepted Version

Creative Commons: Attribution-Noncommercial-No Derivative Works 4.0

Budd, M. E., Stephens, R., Afsar, A., Salimi, S. and Hayes, W. (2019) Exploiting thermally-reversible covalent bonds for the controlled release of microencapsulated isocyanate crosslinkers. Reactive and Functional Polymers, 135. pp. 2331. ISSN 1381-5148 doi:

https://doi.org/10.1016/j.reactfunctpolym.2018.12.008 Available at https://centaur.reading.ac.uk/81149/

It is advisable to refer to the publisher's version if you intend to cite from the work. See Guidance on citing.

To link to this article DOI: http://dx.doi.org/10.1016/j.reactfunctpolym.2018.12.008 Publisher: Elsevier

All outputs in CentAUR are protected by Intellectual Property Rights law, including copyright law. Copyright and IPR is retained by the creators or other copyright holders. Terms and conditions for use of this material are defined in the End User Agreement. 


\section{www.reading.ac.uk/centaur}

\section{CentAUR}

Central Archive at the University of Reading

Reading's research outputs online 


\title{
Exploiting Thermally-Reversible Covalent Bonds for the Controlled Release of Microencapsulated Isocyanate Crosslinkers
}

\author{
M. E. Budd ${ }^{1}$, R. Stephens ${ }^{2}$, A. Afsar ${ }^{1}$, S. Salimi ${ }^{1}$ and W Hayes ${ }^{1 *}$
}

${ }^{1}$ Department of Chemistry, University of Reading, Reading, RG6 6AD, U.K. w.c.hayes@reading.ac.uk, Tel: +44 118378 6491, Fax: +44 1183786331

${ }^{2}$ BAE Systems, Glascoed, Usk, NP15 1XL, U.K.

\begin{abstract}
The paper reports the successful synthesis of microcapsules that incorporate thermally-reversible Diels-Alder or oxime-urethane bonds within the polymer of the microcapsule shell using an interfacial polymerisation technique. The mechanical strength of these microcapsules was found to be dependent on the structure of the thermally-reversible functionality, thus allowing for the design of strong microcapsules that demonstrated excellent stability in one-pot PU formulations. Release of the encapsulated isocyanate crosslinkers using a thermal stimulus demonstrated the potential of this technology for use in the controlled polymerisation of one-pot PU systems.
\end{abstract}

Keywords: Microcapsules, controlled release, Diels-Alder cycloadducts, oximeurethane

\section{Introduction}

Polyurethane (PU) formulations are used extensively in controlled drug delivery systems, coatings, synthetic rubbers, thermoplastics and foams [1-4] and have a market value of EUR ca. 53 billion. [5] The synthesis of PU typically involves the reaction between a polyisocyanate and a polyfunctionalised alcohol in the presence 
of a catalyst. However, as a result of the high reactivity of these components such formulations are not stable, polymerising rapidly even under mild conditions. Microcapsule technologies can, potentially, control the release of highly reactive polyisocyanates and allow the release when desired upon exposure to a suitable stimulus, thus improving the stability of PU formulations and the properties of the resultant products. $[6,7]$

Microcapsules that respond to a range of stimuli have been developed [8] including pressure, [9] chemical (i.e. change in pH or solvent), [10,11] light, [12,13] ultrasound $[14,15]$ and exposure to elevated temperature. [16-24] Release of the core contents from microcapsules using heat can be achieved by heating above the boiling point or degradation temperature of the encapsulated core to increase the internal pressure sufficient to cause rupture of the microcapsule shell. $[17,18,22]$ This approach has been further developed by adhering microcapsules containing blowing agents to magnetic particles - upon application of a magnetic field the particles oscillate creating localised hotspots sufficient to induce degradation of the encapsulated blowing agent, raising the internal pressure and bursting the microcapsules. [21] The contraction of poly( $N$-isopropylacrylamide) (PNIPAM) when exposed to heat has been exploited $[16,19]$ for the thermal release of microcapsules. Upon the application of a thermal stimulus PNIPAM contracts to cause shell wall rupture or exposure of pores within the microcapsule shell wall. A similar strategy has incorporated polymers with low glass transition temperatures $\left(T_{g}\right)$ within the microcapsule shell - upon reaching the $T_{g}$, the microcapsule shell collapses and the core is released. [24] More recently, the thermal release of the core from microcapsules has been achieved by incorporating thermallyreversible Diels-Alder adducts within the shell wall of polyelectrolyte microcapsules synthesised using a complex coacervation technique. [20] Polyelectrolyte 
microcapsules often exhibit poor stability and mechanical strength. PU microcapsules synthesised using an interfacial polymerisation technique have demonstrated excellent strength and stability properties.

Certain covalent bonds are known to undergo a reverse reaction when exposed to heat. Diels-Alder adducts such as maleimide-furan have been employed as thermallydegradable crosslinkers to bestow controlled-release and healable capabilities in polymer systems. [25]. Oxime-urethane bonds are also reversible at elevated temperatures, regenerating the oxime and isocyanate and have been employed [26] as thermally degradable crosslinks in polymers used for the application of thermallystrippable templates employed in the manufacture of microchips.

Herein we describe the encapsulation of isophorone diisocyanate (IPDI) in PU microcapsules that possess thermally-degradable Diels-Alder and oxime-urethane functionalities within the polymer of the microcapsule shell wall. Stability and release studies of the afforded microcapsules have identified the compatibility of such thermally-degradable crosslinkers with polymer microcapsules. This has allowed for the design of a robust encapsulant system that is capable of releasing IPDI into PU formulations when exposed to a heat stimulus (see Scheme 1).

\section{Experimental}

\subsection{Materials}

The chemicals and reagents were either purchased from Sigma Aldrich or supplied by BAE Systems plc. Tetrahydrofuran (THF) was distilled from sodium and benzophenone, dichloromethane was distilled from $\mathrm{CaH}_{2}$ and tetraethylene glycol dimethylether was distilled under vacuum from $\mathrm{CaH}_{2}\left(100^{\circ} \mathrm{C}, 0.1 \mathrm{mmHg}\right)$. All other 
chemicals were used as supplied without further purification. The synthesis of 1, 2 and 3 was carried out according a literature procedure. [26]

\subsection{Chemical and Physical Characterisation}

${ }^{1} \mathrm{H}$ and ${ }^{13} \mathrm{C}$ NMR spectra were obtained using a Bruker Nanobay $400 \mathrm{MHz}$ spectrometer. FTIR spectra were obtained using a Perkin Elmer Spectrum 100, using a PE Universal ATR sampling accessory. VTIR spectroscopy was carried out using a Perkin Elmer Spectrum 100 utilising a Specac variable temperature cell holder employing a static liquid sample cell. Mass spectrometry was conducted using a ThermoFisher Scientific Orbitrap XL LCMS operating an electrospray ioniser (ESI). Optical microscopy was carried out using a Leica DM2500M optical microscope employing a Mettler Toledo FP82HT hot stage and images were recorded using an Infinity 1 digital camera. Microcapsule diameters were measured using Leica Interactive Measurement software. Samples analysed using electron microscopy were imaged using an FEI Quanta FEG 600 Environmental Scanning Electron Microscope operating in a thin aqueous atmosphere (0.68 torr). SEM images of microcapsule cross-sections were obtained by first embedding samples in Agar 100 epoxy resin and cured at $70{ }^{\circ} \mathrm{C}$ for 48 hours. Thin sections were prepared using a Reichert-Jung Ultracut microtome employing a glass knife. Tensile stress tests were carried out using a single column AML tensiometer stretching the samples at the speed of $10 \mathrm{~mm} / \mathrm{min}$.

\subsection{Conversion of Protected Maleic Anhydride to Maleimide 4}

Protected maleic anhydride 1 (1.53 g, $9.3 \mathrm{mmol})$ and 3-amino-1-propanol (0.830 g, $11.1 \mathrm{mmol})$ were dissolved in $\mathrm{MeOH}(50 \mathrm{~mL})$ and maintained under reflux for a period of 18 hours. The solvent was removed in vacuo to leave a yellow coloured oil that was purified by column chromatography $\left(\mathrm{R}_{\mathrm{f}}=0.29,2 \% \mathrm{MeOH} / \mathrm{CHCl}_{3}\right)$ to afford a white 
solid 4 (0.69 g, 36 \%) (m.p. 119-124 ${ }^{\circ} \mathrm{C}$ ). ${ }^{1} \mathrm{H}$ NMR (400 MHz, Acetone-d6): $\delta 1.70$ (quint., $J=6.5 \mathrm{~Hz}, 2 \mathrm{H}), 2.93(\mathrm{~s}, 2 \mathrm{H}), 3.49(\mathrm{~s}, 1 \mathrm{H}), 3.51(\mathrm{t}, J=5.0 \mathrm{~Hz}, 2 \mathrm{H}), 3.52(\mathrm{t}, J=7.0 \mathrm{~Hz}$, 2H), $5.15(\mathrm{~s}, 2 \mathrm{H}), 6.59(\mathrm{~s}, 2 \mathrm{H}) ;{ }^{13} \mathrm{C}$ NMR (100 MHz, Acetone-d $)$ : $\delta$ 31.6, 36.2, 48.3, 59.7, 81.8, 137.4, 177.4; FTIR (ATR) v $\left(\mathrm{cm}^{-1}\right): 3511(\mathrm{O}-\mathrm{H}), 3099(\mathrm{C}-\mathrm{H}), 2952(\mathrm{C}-\mathrm{H})$, $1691(\mathrm{C}=\mathrm{O}), 1405(\mathrm{C}-\mathrm{N}), 1158(\mathrm{C}-\mathrm{O})$; ESIMS calculated mass $\left(\mathrm{C}_{11} \mathrm{H}_{14} \mathrm{O}{ }_{4} \mathrm{~N}\right)^{+} 224.0917$ found 224.0918.

\subsection{Deprotection to Form Hydroxy-Functionalised Maleimide 5}

Protected maleimide $(0.650 \mathrm{~g}, 2.9 \mathrm{mmol}) 4$ was dissolved in toluene $(20 \mathrm{~mL})$ and maintained under reflux for a period of 7 hours. The solvent was removed in vacuo to leave a pale yellow coloured oil 5 (0.375 g, $83 \%) .{ }^{1} \mathrm{H}$ NMR (400 $\left.\mathrm{MHz}, \mathrm{CDCl}_{3}\right): \delta 1.80$ (quint. $J=6.0 \mathrm{~Hz}, 2 \mathrm{H}$ ), 2.60 (br., 1H), 3.59 (br., 2H), 3.69 (t, J = $7.0 \mathrm{~Hz}, 2 \mathrm{H}$ ), 6.74 (s, $2 \mathrm{H}) ;{ }^{13} \mathrm{C}$ NMR $\left(100 \mathrm{MHz}, \mathrm{CDCl}_{3}\right): \delta 31.2,34.3,59.1,134.2,171.3 ; \mathrm{FTIR}(\mathrm{ATR}) \vee\left(\mathrm{cm}^{-}\right.$ $\left.{ }^{1}\right): 3478(\mathrm{O}-\mathrm{H}), 3110(\mathrm{C}-\mathrm{H}), 2954(\mathrm{C}-\mathrm{H}), 1695(\mathrm{C}=\mathrm{O}), 1409$ (C-N), 1149 (C-O); ESIMS calculated mass $\left(\mathrm{C}_{7} \mathrm{H}_{10} \mathrm{O}_{3} \mathrm{~N}\right)+156.0655$ found 156.0654 .

\subsection{Synthesis of Dihydroxy-Functionalised Diels-Alder Adduct 6}

Hydroxy-functionalised maleimide $5(0.340 \mathrm{~g}, 2.19 \mathrm{mmol})$ and furfuryl alcohol $(0.258 \mathrm{~g}$, $2.6 \mathrm{mmol})$ were dissolved in toluene $(40 \mathrm{~mL})$ and maintained at $80^{\circ} \mathrm{C}$ for a period of 72 hours. The solvent was removed in vacuo to leave a yellow coloured oil that was

purified by column chromatography $\left(\mathrm{R}_{\mathrm{f}}=0.15,5 \% \mathrm{MeOH} / \mathrm{CHCl}_{3}\right)$ to afford a colourless oil 6 obtained as a mixture of exo and endo isomers (7:3) that slowly transformed to the exo isomer over a period of several months $(0.426 \mathrm{~g}, 77 \%)$. Exoisomer: ${ }^{1} \mathrm{H} \mathrm{NMR}\left(400 \mathrm{MHz}, \mathrm{CDCl}_{3}\right): \delta 1.76$ (quint., $\left.J=6.0 \mathrm{~Hz}, 2 \mathrm{H}\right), 3.00(q, J=6.5 \mathrm{~Hz}$, $1 \mathrm{H}), 3.49(\mathrm{~m}, 1 \mathrm{H}), 3.49(\mathrm{~m}, 1 \mathrm{H}), 3.54(\mathrm{t}, J=6.0 \mathrm{~Hz}, 2 \mathrm{H}), 3.66(\mathrm{t}, J=6.0 \mathrm{~Hz}, 2 \mathrm{H}), 4.07$ $(\mathrm{s}, 2 \mathrm{H}), 6.55(\mathrm{dd}, J=1.0,6.0 \mathrm{~Hz}, 1 \mathrm{H}), 6.62(\mathrm{~d}, J=6.0 \mathrm{~Hz}, 1 \mathrm{H}),{ }^{13} \mathrm{C} \mathrm{NMR}(100 \mathrm{MHz}$, 
$\left.\mathrm{CDCl}_{3}\right): \delta 30.3,35.4,48.1,50.0,58.8,60.6,80.9,91.4,137.0,138.3,176.6,176.7$ Endo-isomer: ${ }^{1} \mathrm{H} \mathrm{NMR}\left(400 \mathrm{MHz}, \mathrm{CDCl}_{3}\right): \delta 1.65$ (quint., $\left.J=6.0 \mathrm{~Hz}, 2 \mathrm{H}\right), 3.49(\mathrm{~m}, 1 \mathrm{H}$ ), $3.50(\mathrm{~m}, 2 \mathrm{H}), 3.68(\mathrm{t}, J=6.0 \mathrm{~Hz}, 2 \mathrm{H}), 4.21(\mathrm{~m}, 1 \mathrm{H}), 5.29(\mathrm{~s}, 2 \mathrm{H}), 5.31(\mathrm{~d}, J=6.0 \mathrm{~Hz}$, $1 \mathrm{H}), 6.35(\mathrm{~d}, J=6.0 \mathrm{~Hz}, 1 \mathrm{H}), 6.47(\mathrm{dd}, J=1.0,6.0 \mathrm{~Hz}, 1 \mathrm{H}) ;{ }^{13} \mathrm{C} \mathrm{NMR}(100 \mathrm{MHz}$, $\left.\mathrm{CDCl}_{3}\right): \delta 30.4,35.1,46.1,48.2,59.0,61.3,79.4,92.1,134.9,135.7,175.5,175.9$; FTIR (ATR) v (cm-1): $3460(\mathrm{O}-\mathrm{H}), 3112(\mathrm{C}-\mathrm{H}), 2960(\mathrm{C}-\mathrm{H}), 1683(\mathrm{C}=\mathrm{O}), 1404(\mathrm{C}-\mathrm{N})$, 1172 (C-O); ESIMS calculated mass $\left.\left(\mathrm{C}_{12} \mathrm{H}_{16} \mathrm{O}_{5} \mathrm{~N}\right)\right)^{+} 254.1023$ found 254.1025.

\subsection{Synthesis of Isocyanate-Terminated Prepolymer 7}

Dihydroxy-functionalised Diels-Alder adduct $6(0.393 \mathrm{~g}, 1.6 \mathrm{mmol})$ and toluene-2,4diisocyanate (TDI) $(0.757 \mathrm{~g}, 4.4 \mathrm{mmol})$ were dissolved in tetrahydrofuran (THF) (15 $\mathrm{mL}$ ) and maintained under reflux for a period of 18 hours under an atmosphere of argon. The solvent was removed in vacuo and excess TDI was removed by washing with cyclohexane $(3 \times 20 \mathrm{~mL})$ at $80^{\circ} \mathrm{C}$ to leave a yellow coloured solid $7(0.926 \mathrm{~g}, 99 \%)$ $\left(125-129^{\circ} \mathrm{C}\right)$. FTIR $($ ATR $) \vee\left(\mathrm{cm}^{-1}\right): 3340(\mathrm{~N}-\mathrm{H}), 3124(\mathrm{C}-\mathrm{H}), 2947(\mathrm{C}-\mathrm{H}), 2265(\mathrm{NCO})$, $1696(\mathrm{C}=\mathrm{O}), 1537(\mathrm{C}-\mathrm{N}), 1220$ (C-O); ESIMS of 5 derivative from reaction with $\mathrm{MeOH}$, calculated mass $\left(\mathrm{C}_{32} \mathrm{H}_{35} \mathrm{O}_{11} \mathrm{~N}_{5} \mathrm{Na}\right)^{+} 688.2225$ found 688.2225 .

\subsection{Synthesis of oxime-urethane 8}

Protected 4'-hydroxyacetophenone oxime $3(0.163 \mathrm{~g}, 0.6 \mathrm{mmol})$, dibutyltin dilaurate (DBTDL) (0.002 g, $0.003 \mathrm{mmol})$ and tetramethylxylylene diisocyanate (TMXDI) (0.05 g, $0.2 \mathrm{mmol})$ dissolved in THF (10 mL) and maintained under reflux for 24 hours. The solvent was removed in vacuo to leave a pale yellow oil which was purified by column chromatography ( $\mathrm{R}_{\mathrm{f}} 0.19,20 \% \mathrm{EtOAc/hexane)}$ to give a white solid $8(0.132 \mathrm{~g}, 88 \%)$ (m.p. 43-44 $\left.{ }^{\circ} \mathrm{C}\right) .{ }^{1} \mathrm{H}$ NMR $\left(400 \mathrm{MHz}, \mathrm{CDCl}_{3}\right): \delta 0.22$ (s, 12H), 0.99 (s, 18H), 1.78 (s, 12H), $2.36(\mathrm{~s}, 6 \mathrm{H}), 6.85(\mathrm{~d}, J=9.0 \mathrm{~Hz}, 4 \mathrm{H}), 6.88(\mathrm{~m}, 2 \mathrm{H}), 7.35(\mathrm{~m}, 3 \mathrm{H}), 7.54(\mathrm{~m}, 1 \mathrm{H})$, 
$7.56(\mathrm{~d}, J=9.0 \mathrm{~Hz}, 4 \mathrm{H}) ;{ }^{13} \mathrm{C} \mathrm{NMR}\left(100 \mathrm{MHz}, \mathrm{CDCl}_{3}\right): \delta-4.4,14.2,18.3,25.6,29.1$, 56.0, 120.3, 121.2, 123.3, 127.7, 128.1, 128.7, 147.0, 153.5, 158.0, 159.1; FTIR (ATR) $v\left(\mathrm{~cm}^{-1}\right): 2928(\mathrm{C}-\mathrm{H}), 2857(\mathrm{C}-\mathrm{H}), 1722(\mathrm{C}=\mathrm{O}), 1601(\mathrm{C}=\mathrm{N}), 1496(\mathrm{C}-\mathrm{N}), 1254(\mathrm{Si}-\mathrm{O})$, 1172 (C-O), 905 (N-O); ESIMS calculated mass $\left(\mathrm{C}_{42} \mathrm{H}_{62} \mathrm{O}_{6} \mathrm{~N}_{4} \mathrm{Si}_{2}+\mathrm{H}\right)+775.4281$ found 775.4286.

\subsection{Deprotection of silyl-ethers to form $\mathbf{9}$}

Oxime-urethane $8(0.781 \mathrm{~g}, 1.0 \mathrm{mmol})$ was dissolved in THF $(20 \mathrm{~mL})$ and tetrabutylammonium fluoride (TBAF) $(1.0 \mathrm{M})(1.0 \mathrm{ml}, 1.0 \mathrm{mmol})$ was added and stirred at room temperature for 1 hour. The reaction was quenched with $\mathrm{NH}_{4} \mathrm{Cl}(20 \mathrm{~mL})$ (saturated) and the product extracted with EtOAc $(50 \mathrm{~mL})$. The organic extract was washed with $\mathrm{H}_{2} \mathrm{O}(3 \times 50 \mathrm{~mL})$, dried over $\mathrm{MgSO}_{4}$ followed by filtration and the solvent removed in vacuo to give a pale yellow solid which was purified by washing sequentially with $\mathrm{Et}_{2} \mathrm{O}(3 \times 50 \mathrm{~mL})$ and $\mathrm{CHCl}_{3}(2 \times 50 \mathrm{~mL})$ leaving a white solid $9(0.490$ g, $90 \%$ ) (m.p. $\left.92-100{ }^{\circ} \mathrm{C}\right) .{ }^{1} \mathrm{H}$ NMR (400 MHz, DMSO-d6): $\delta 1.63$ (s, 12H), 2.29 (s, $6 \mathrm{H}), 6.81(\mathrm{~d}, J=9.0 \mathrm{~Hz}, 4 \mathrm{H}), 7.27(\mathrm{~m}, 3 \mathrm{H}), 7.46(\mathrm{~m}, 1 \mathrm{H}), 7.55(\mathrm{~m}, 2 \mathrm{H}), 7.61(\mathrm{~d}, J=$ $8.0 \mathrm{~Hz}, 4 \mathrm{H}), 9.93$ (s, 2H); ${ }^{13} \mathrm{C}$ NMR (100 MHz, DMSO-d6): $\delta$ 13.4, 29.3, 55.1, 115.3, 121.2, 122.7, 125.3, 127.8, 128.3, 147.2, 152.8, 159.1, 159.5; FTIR (ATR) $v\left(\mathrm{~cm}^{-1}\right)$ : $3378(\mathrm{O}-\mathrm{H}), 3230(\mathrm{~N}-\mathrm{H}), 2993(\mathrm{C}-\mathrm{H}), 2953(\mathrm{C}-\mathrm{H}), 1706(\mathrm{C}=\mathrm{O}), 1605(\mathrm{C}=\mathrm{N}), 1499(\mathrm{C}-$ $\mathrm{N}), 1238(\mathrm{C}-\mathrm{O}), 911(\mathrm{~N}-\mathrm{O})$; ESIMS calculated mass $\left(\mathrm{C}_{30} \mathrm{H}_{34} \mathrm{O}_{6} \mathrm{~N}_{4}+\mathrm{Na}\right)^{+} 569.2371$ found 569.2367.

\subsection{Synthesis of Isocyanate-Terminated Prepolymer 10}

Deprotected oxime-urethane $9(0.603 \mathrm{~g}, 1.1 \mathrm{mmol})$ and TDI $(0.538 \mathrm{~g}, 3.1 \mathrm{mmol})$ were dissolved in THF (30 mL) and maintained under reflux for 24 hours. The solvent was removed in vacuo and excess TDI removed by washing with cyclohexane $(3 \times 60 \mathrm{~mL})$ 
at $80{ }^{\circ} \mathrm{C}$ to leave a yellow solid $10(0.822 \mathrm{~g}, 84 \%)$ (m.p. $\left.86-91^{\circ} \mathrm{C}\right)$. FTIR (ATR) $\vee\left(\mathrm{cm}^{-}\right.$ 1): $3357(\mathrm{~N}-\mathrm{H}), 2979(\mathrm{C}-\mathrm{H}), 2924(\mathrm{C}-\mathrm{H}), 2255(\mathrm{NCO}), 1723(\mathrm{C}=\mathrm{O}), 1593(\mathrm{C}=\mathrm{N}), 1505$ (C-N), $1193(\mathrm{C}-\mathrm{O}), 901(\mathrm{~N}-\mathrm{O})$; ESIMS calculated mass $917.3229\left(\mathrm{C}_{48} \mathrm{H}_{46} \mathrm{O}_{10} \mathrm{~N}_{8}+\mathrm{Na}\right)^{+}$ found 917.3233 .

\subsection{Microencapsulation of Isophorone Diisocyanate}

General procedure for synthesis of microencapsulated isophorone diisocyanate (IPDI) Gum arabic $(9 \mathrm{~g})$ was dispersed in $\mathrm{H}_{2} \mathrm{O}(60 \mathrm{~mL})$ in a $150 \mathrm{~mL}$ beaker with the aid of mechanical agitation at a rate of $1000 \mathrm{rpm}$. Prepolymer and IPDI were dissolved in a hydrophobic solvent. This solution was added to the aqueous solution and the resultant emulsion heated to $70^{\circ} \mathrm{C}$ at a rate of $10^{\circ} \mathrm{C} /$ minute. When the temperature reached $50^{\circ} \mathrm{C}, 1,4$-butanediol $(5.2 \mathrm{~g}, 56.6 \mathrm{mmol})$ was added and agitated at the same rate for an additional 30 seconds. The mixture was agitated at a rate of $150 \mathrm{rpm}$ for 45 minutes at $70{ }^{\circ} \mathrm{C}$ followed by a further 2 hours at room temperature. After this period, agitation was ceased, $\mathrm{H}_{2} \mathrm{O}(100 \mathrm{~mL})$ was added and the generated microcapsules allowed to settle at the bottom of the beaker over a period of 1 hour at room temperature. The aqueous solution was decanted to leave polyurethane microcapsules that were collected by vacuum filtration, washed with $\mathrm{H}_{2} \mathrm{O}$ and then air dried for a period of 48 hours $(0.153 \mathrm{~g})$. For parameters associated with the synthetic process, including rate of agitation and reaction time, please refer to the Supporting Information (SI).

\subsection{Variable Temperature Infrared Spectroscopy}

Oxime-urethane $\mathbf{8}$ was dissolved in dried tetraethylene glycol dimethyl ether to a concentration of $3.0 \mathrm{M}$. This solution was injected into a variable temperature IR spectroscopy cell utilising $\mathrm{NaCl}$ windows separated by a $0.050 \mathrm{~mm}$ PTFE spacer. The cell was placed in a variable temperature cell holder and an IR spectrum recorded at 
$10{ }^{\circ} \mathrm{C}$ increments with a FTIR spectrometer and the appearance of an absorption corresponding to the isocyanate functionality formed upon dissociation was observed.

\subsection{Preparation and Tensile Testing of Polymer Films}

PU-microcapsule M1 mixture and PU-microcapsule M2 mixture were prepared by mixing the respective microcapsules $(18 \mathrm{mg})$ with hydroxy-terminated polyalkene (100 $\mathrm{mg}$ ) and dibutyltin dilaurate (DBTDL) $(0.24 \mathrm{mg})$. PU mixture was prepared by mixing IPDI (11 mg), hydroxy-terminated polyalkene $(100 \mathrm{mg})$ and DBTDL $(0.24 \mathrm{mg})$. The mixtures were pasted in a $1 \mathrm{~cm}^{2}$ area, $0.5 \mathrm{~mm}$ thick, on microscope slides and covered with a second layer of microscope slides. The films were heated to $150{ }^{\circ} \mathrm{C}$ for 24 hours followed by a further 24 hours at $60^{\circ} \mathrm{C}$.

Lap shear testing was performed on the samples before and after heating by griping the slides between the tensile tester clamps and pulling them apart at $1 \mathrm{~mm} / \mathrm{min}$.

\section{Results and Discussion}

\subsection{Prepolymer Synthesis}

PU microcapsules were synthesised using an interfacial polymerisation approach as this route has been shown [6] to afford robust encapsulant systems. This first required the preparation of isocyanate-terminated prepolymers 7 and 10 containing the desired thermally-degradable crosslinkers. To this end a synthetic approach analogous to that developed [26] by Heath et al. was employed.

Incorporation of Diels-Alder crosslinkers into a prepolymer $\mathbf{7}$ first involved the initial protection of maleic anhydride with furan to form a Diels-Alder adduct 1. The reaction of this adduct with 3-amino-1-propanol followed by deprotection afforded a hydroxyfunctionalised maleimide 5. Subsequent reaction with furfuryl alcohol followed by reaction of excess toluene-2,4-diisocyanate (TDI) led to the formation of an 
isocyanate-terminated prepolymer $\mathbf{7}$ that is capable of further chain extension to form polyurethane microcapsules (Scheme 2). [6,11]

The synthesis of a prepolymer $\mathbf{1 0}$ containing an oxime-urethane involved initial protection of a hydroxy-functionalised ketone to give $\mathbf{2}$ followed by the conversion to the corresponding oxime 3 . The reaction of the generated oxime with tetramethylxylylene diisocyanate (TMXDI) afforded a thermally-reversible oximeurethane 8. Deprotection to reveal the hydroxyl functionality 9 then allowed reaction with toluene-2,4-diisocyanate (TDI) to afford the desired isocyanate-terminated prepolymer $\mathbf{1 0}$ (Scheme 3).

The presence of the active isocyanate-termini of the prepolymers $\mathbf{7}$ and $\mathbf{1 0}$ was confirmed using FTIR spectroscopy, revealing the presence of a broad absorption at $2268 \mathrm{~cm}^{-1}$ corresponding to the isocyanates moiety. This functionality can also be quantified by titrational analysis, [27] which revealed an isocyanate content of $12 \%$ and $13 \%$ for prepolymers 7 and $\mathbf{1 0}$ respectively (see SI file for the calculation).

${ }^{1} \mathrm{H}$ NMR spectroscopy was employed to investigate the potential of the maleimidefuran Diels-Alder adduct to dissociate upon exposure to heat. [28] The dihydroxyfunctionalised maleimide furan 6 was dissolved in deuterated DMSO and analysed using ${ }^{1} \mathrm{H}$ NMR spectroscopy before and after exposure to a temperature of $140{ }^{\circ} \mathrm{C}$ for 15 minutes (Figure 1). Analysis revealed that after exposure to this temperature the Diels-Alder adduct had almost completely dissociated regenerating the maleimide $\mathbf{5}$ and furan components.

The dissociation of the thermally-labile oxime-urethane was observed using variable temperature infra-red spectroscopy. [29-31] Figure 2a displays the VTIR spectra of 8. At $20^{\circ} \mathrm{C}$, an absorbance corresponding to the $\mathrm{C}=\mathrm{O}$ functionality of the oxime-urethane 
at $1757 \mathrm{~cm}^{-1}$ was observed. Upon increasing the temperature to $70{ }^{\circ} \mathrm{C}$, an absorbance characteristic of the isocyanate moiety appeared at $2263 \mathrm{~cm}^{-1}$. Further increasing the temperature led to an increase in the intensity of this absorption indicating the dissociation occurred over a broad temperature range. Upon reaching $140{ }^{\circ} \mathrm{C}$ an additional absorption at $2337 \mathrm{~cm}^{-1}$ is observed which may be attributed to the formation of $\mathrm{CO}_{2}$, released by reaction of isocyanate and water. This result can be represented quantitatively by measuring the absorption intensities as a function of temperature. A linear increase in absorption intensity of the NCO moiety with increasing temperature is observed between $70-130^{\circ} \mathrm{C}$, after which a small decrease in intensity is observed, likely caused by overlapping with the $\mathrm{CO}_{2}$ absorption at $2337 \mathrm{~cm}^{-1}$. When compared to the intensity of the NCO absorption, the decrease in intensity of the absorption corresponding to the $\mathrm{N}-\mathrm{H}$ stretching vibration at $3408 \mathrm{~cm}^{-1}$ of the oxime-urethane moiety was much smaller (see Figure $2 b$ ) on account of the decarboxylation of carbamic acid which resulted from the reaction of the generated isocyanate and residual water. The resultant amine is capable of reacting with further isocyanate to form urea linkages. To support this observation, pure TMXDI was heated under the same conditions and an analogous result was observed. In this case, at room temperature a characteristic isocyanate vibration was observed at $2271 \mathrm{~cm}^{-1}$ and upon further heating to $140{ }^{\circ} \mathrm{C}$, an absorption appeared at $2380 \mathrm{~cm}^{-1}$. In addition, absorptions at 3420 and 1734 correspond to $\mathrm{N}-\mathrm{H}$ and $\mathrm{C}=\mathrm{O}$ vibrations, respectively, correlating to the formation of a urea (see SI for further details).

\subsection{Microcapsules Synthesis}

The microencapsulation of IPDI in polyurethane microcapsules M1, M2 using the prepolymers 7, 10 employed an interfacial polymerisation technique similar to that developed by White and co-workers. [6] The prepolymer 7, 10 and IPDI were dissolved 
in a hydrophobic solvent (o-methoxyacetophenone and ethyl phenylacetate for $\mathbf{7}$ and 10 respectively) and emulsified in a surfactant solution of gum arabic with the aid of mechanical agitation. Upon the addition of a water soluble chain extender, 1,4butanediol, a reaction occurred at the oil-water interface to form a polyurethane shell that contained thermally-degradable crosslinks (Figure 3). The reaction of IPDI was avoided as the high reactivity of TDI-based prepolymers outcompeted the relatively less reactive NCO moieties of IPDI. The generated microcapsules were isolated by filtration, followed by washing with water and allowing to air dry for 48 hours prior to analysis. The properties of the microcapsules were measured using a range of analytical techniques including - optical microscopy, [32] scanning electron microscopy, [33] FTIR spectroscopy [6] and ${ }^{1} \mathrm{H}$ NMR spectroscopy. [34]

Confirmation of the successful microencapsulation of a liquid core was observed by crushing the microcapsules between two microscope slides which reveal the release of a liquid core. Analysis using optical microscopy allowed measurement of the microcapsule diameter which revealed that the average diameter of the microcapsules was $76 \mu \mathrm{m}$ within a range of $29-138 \mu \mathrm{m}$ for $\mathbf{M} 1$ and $68 \mu \mathrm{m}$ within a range of $22-117$ $\mu \mathrm{m}$ for M2. This result is within the expected literature values for microcapsules synthesised at a rate of agitation of $1000 \mathrm{rpm}$. [6] The diameter and size distribution of microcapsules can be controlled by changing the rate of agitation and surfactant concentration. [35]

Analysis of the microcapsules using an environmental scanning electron microscope operating in a thin aqueous atmosphere (0.68 torr) revealed that spherical mononuclear microcapsules had been generated and they possessed a smooth external surface along with a rough internal surface and this is in accordance with literature studies. [6] A sample of the microcapsules was embedded in an epoxy resin 
and cross-sections prepared using an ultramicrotome employing a glass knife and this was then imaged using the conditions outlined above. [36] An average shell wall thickness of $3.45 \mu \mathrm{m}$ and $2.45 \mu \mathrm{m}$ was observed for M1 and M2 respectively, within the reported literature range of microcapsules prepared using a similar interfacial polymerisation technique described by Yang et al. (SEM images available in SI). [6] Microcapsules were crushed to release the liquid core and the crushed material was analysed using FTIR spectroscopy. [6,37] A broad absorption at $2255 \mathrm{~cm}^{-1}$ was observed characteristic of the isocyanate stretching vibration. This absorption corresponds to the presence of NCO moieties of encapsulated IPDI and prepolymer 7, 10 (spectra available in SI). [6,37-39] A further notable absorption at $1736 \mathrm{~cm}^{-1}$ was observed that is likely to correspond to the urethane carbonyl functional group of the polyurethane microcapsule shell wall

In addition to FTIR spectroscopy, ${ }^{1} \mathrm{H}$ NMR spectroscopic analysis was also employed to confirm the successful encapsulation of IPDI. [31] Microcapsules were crushed and the released core was washed with $\mathrm{CDCl}_{3}$. The washings were filtered to remove the solid shell wall and analysed with ${ }^{1} \mathrm{H}$ NMR spectroscopy. The ${ }^{1} \mathrm{H}$ NMR spectrum was compared to spectra of IPDI and the hydrophobic solvent and a clear overlap between the microcapsule core and the individual components was observed corroborating the observation of the successful microencapsulation of IPDI crosslinker. Chemical shifts corresponding to prepolymers $\mathbf{7 , 1 0}$ were not observed in the spectra. This absence is a result of the poor solubility of the prepolymers in $\mathrm{CDCl}_{3}$. Methyl 4-nitrobenzoate was employed as an internal standard since the resonances did not overlap with those of the microcapsule core components. Comparison of the integration of resonances of the internal standard observed at 8.23-8.29 ppm with those of IPDI ppm and the hydrophobic solvents $(6.98 \mathrm{ppm}$ and $8.25 \mathrm{ppm}$ for o-methoxyacetophenone and ethyl 
phenylacetate respectively) allowed the composition of the microcapsule core to be quantified. Analysis of $\mathbf{M 1}$ revealed the core was composed of 80 wt. \% IPDI, and 20 wt. \% o-methoxyacetophenone demonstrating a significantly higher portion of IPDI encapsulated than previously reported $[6,37]$ using an interfacial polymerisation microencapsulation technique. The high percentage of IPDI may be attributed to leaching of the volatile o-methoxyacetophenone solvent through the permeable microcapsule shell wall. [40,41] Analysis of $\mathbf{M 2}$ revealed the core was composed of 60 $\mathrm{wt} / \mathrm{wt} \% \mathrm{IPDI}$ and $40 \mathrm{wt} / \mathrm{wt} \%$ ethyl phenylacetate, similar to results previously reported. $[6,37]$

\subsection{Release of Microcapsules with a Heat Stimulus}

The capability of these microcapsules to release isocyanate crosslinkers upon exposure to a stimulus of heat was investigated. Microcapsules M1, M2 were heated to $150^{\circ} \mathrm{C}$ at a rate of $10^{\circ} \mathrm{C} /$ minute and to $200^{\circ} \mathrm{C}$ at a rate of $1^{\circ} \mathrm{C} /$ minute respectively using a hot stage mounted to an optical microscope and images recorded using a digital camera. In addition to optical microscopy, SEM images were obtained before and after heating. Upon heating $\mathbf{M} 1$ to $125^{\circ} \mathrm{C}$ the shell wall of the microcapsules began to dissociate and this dissociation occurred rapidly above this temperature reaching complete dissociation and release of the core from the microcapsules by $140^{\circ} \mathrm{C}$. As expected, SEM analysis of the microcapsules after heating revealed the absence of spherical-shaped microcapsules suggesting complete dissociation of the microcapsules had been achieved (Figure 4). Release of IPDI and TMXDI from M2 was observed upon reaching a temperature of $150^{\circ} \mathrm{C}$. [42] Upon cooling, a brittle solid material was formed and SEM analysis observed 'plate-like' structures (Figure 4f). Microcapsules not containing a thermally-reversible Diels-Alder adduct, designated as 'control microcapsules', were also heated to $140^{\circ} \mathrm{C}$. At this temperature the shells of 
the control microcapsules began to pucker, suggesting the core had leached from the microcapsules. However, dissociation of the shell wall was not observed.

\subsection{Release of Microcapsule Core in PU Formulation}

The stability of the microcapsules in PU rubber formulations was investigated. Microcapsules M1, M2 (18 mg) were mixed with hydroxy-terminated polyalkene (100 $\mathrm{mg}$ ) and dibutyltin dilaurate (DBTDL) $(0.24 \mathrm{mg})$ designated as PUM1 mixture and PUM2 mixture respectively and agitated for 5 minutes with an overhead stirrer. Microcapsules M1 possessed insufficient mechanical strength to survive the high shear mixing conditions and thus release studies of $\mathbf{M 1}$ were not investigated. The high steric hindrance and non-linear structure of the Diels-Alder prepolymer 7 may have prevented the formation of a strong polymer shell. Conversely, oxime-urethane crosslinkages form strong microcapsules M2 that demonstrated excellent survivability during mixing. This observation identifies the key structural parameters of prepolymers that are required to form robust microencapsulation systems. A PU mixture of IPDI, hydroxy-terminated polyalkene and DBTDL was also prepared and each mixture was placed in $1 \mathrm{~cm}^{2}$ area between two microscope slides. An application of force was applied to the each of the two slides in opposite directions using a tensometer. The PU and PUM2 mixtures were exposed to $60{ }^{\circ} \mathrm{C}$ for a period of 24 hours. Tensile testing after this time revealed that polymerisation of the PU mixture had occurred after this time. In contrast, polymerisation was not observed in the PUM2 mixture, demonstrating how microencapsulation technology can be employed in stable one-pot PU formulations (Figure 5).

The potential of the generated microcapsules M2 for the controlled delivery of IPDI in PU formulations using an external stimulus of heat was investigated. PUM2 mixture was placed between two microscope slides and exposed to $150{ }^{\circ} \mathrm{C}$ for a period of 24 
hours followed by a further 24 hours at $60^{\circ} \mathrm{C}$. Tensile testing was performed before and after heating and revealed that upon exposure to heat an increase in the tensile strength was observed, suggesting that IPDI was successfully released from the microcapsules and polymerisation was achieved (Figure 6).

\section{Conclusions}

Isocyanate-terminated pre-polymers that incorporating either thermally-reversible Diels-Alder adducts or oxime-urethane bonds have been synthesised successfully and were used to synthesise microcapsules containing active IPDI using an interfacial polymerisation technique. The release of active isocyanate crosslinkers was achieved upon exposing the microcapsules to a heat stimulus. The mechanical strength of the microcapsules was dependent on the structure of the thermally-reversible groups, the non-linear and high steric structure of the Diels-Alder adduct prevented the formation of mechanically robust microcapsules. Microcapsules containing a thermallyreversible oxime-urethane demonstrated excellent mechanical strength and stability in PU formulations. Release studies of the microcapsules have demonstrated the potential of this technology for use in the controlled polymerisation of polymer systems.

\section{Acknowledgements}

The authors would like to acknowledge BAE Systems for funding a PhD studentship (MEB) and also the University of Reading for access to analytical instrumentation in the Chemical Analysis Facility.

\section{Data Availability}

The raw/processed data required to reproduce these findings cannot be shared at this time due to technical or time limitations. Processed data can be found in the associated Supporting Information file. 


\section{References}

[1] S. Lee and D. Randall, The Polyurethanes Book, Wiley, Chichester, 2002.

[2] M. Shoaib, A. Bahadur, A. Saeed, M. S. Rahman and M. N. Naseer, Biocompatible, $\mathrm{pH}$-responsive, and biodegradable polyurethanes as smart anti-cancer drug delivery carriers, React. Funct. Polym. 127 (2018) 153-160.

[3] A. Bahadur, A. Saeed, S. Iqbal, M. Shoaib, M. S. Rahman, M. I. Bashir, M. Asghar, M. A. Ali and T. Mahmood, Biocompatible waterborne polyurethane-urea elastomer as intelligent anticancer drug release matrix: A sustained drug release study, React. Funct. Polym. 119 (2017) 57-63.

[4] Y. Chen, R. Wang, J. Zhou, H. Fan and B. Shi, On-demand drug delivery from temperature-responsive polyurethane membrane, React. Funct. Polym. 71 (2011) $525-535$.

[5] S. Tomas, J. Datta, J. T. Haponiuk and A. Reghunadhan, Polyurethane Polymers, Elsevier, Oxford, 2017.

[6] J. Yang, M. W. Keller, J. S. Moore, S. R. White and N. R. Sottos, Microencapsulation of isocyanates for self-healing polymers, Macromolecules 41 (2008) 9650-9655.

[7] L. -T. T. Nguyen, X. K. D. Hillewaere, R. F. A. Teixeira, O. van den Berg, F. E. Du Prez, Efficient microencapsulation of a liquid isocyanate with in situ shell functionalization, Polym. Chem. 6 (2015) 1159-1170.

[8] A. P. Esser-Kahn, S. A. Odom, N. R. Sottos, S. R. White and J. S. Moore, Triggered release from polymer capsules, Macromolecules 44 (2011) 5539-5553.

[9] T. Ohtsubo, S. Tsuda and K. Tsuji, A study of the physical strength of fenitrothion microcapsules, Polymer 32 (1991) 2395-2399. 
[10] A. N. Zelikin, J. F. Quinn and F. Caruso, Disulfide cross-linked polymer capsules: en route to biodeconstructible systems, Biomacromolecules 7 (2006) 27-30.

[11] A. P. Esser-Kahn, N. R. Sottos, S. R, White and J. S. Moore, Programmable microcapsules from self-immolative polymers, J. Am. Chem. Soc. 132 (2010) 1026610268.

[12] N. Fomina, C. McFearin, M. Sermsakdi, O. Edigin and A. Almutairi, UV and nearIR triggered release from polymeric nanoparticles, J. Am. Chem. Soc. 132 (2010) 9540-9542.

[13] T. Vöpel, R. Scholz, L. Davico, M. Groß, S. Büning, S. Kareth, E. Weidner and S. Ebbinghaus, Infrared laser triggered release of bioactive compounds from single hard shell microcapsules, Chem. Commun. 51 (2015) 6913-6916.

[14] M. R. Böhmer, C. H. T. Chlon, B. I. Raju, C. T. Chin, T. Shevchenko and A. L. Klibanov, Focused ultrasound and microbubbles for enhanced extravasation, J. Control. Release 148 (2010) 18-24.

[15] S. Kennedy, J. Hu, C. Kearney, H. Skaat, L. Gu, M. Gentili, H. Vandenburgh and D. Mooney, Sequential release of nanoparticle payloads from ultrasonically burstable capsules, Biomaterials 75 (2016) 91-101.

[16] L. Chu, S. Park, T. Yamaguchi and S. Nakao, Preparation of micron-sized monodispersed thermoresponsive core-shell microcapsules, Langmuir 18 (2002) 1856-1864.

[17] S. J. Pastine, D. Okawa, A. Zettl and J. M. J. Fréchet, Chemicals On demand with phototriggerable microcapsules, J. Am. Chem. Soc. 131 (2009) 13586-13587.

[18] M. Volz, P. Walther, U. Ziener and K. Landfester, Nano-explosions of nanoparticles for sudden release of substances by embedded azo-components as obtained via the miniemulsion process, Macromol. Mater. Eng. 292 (2007) 1237-1244. 
[19] W. Yang, R. Xie, X. Pang, X. Ju and L. Chu, Preparation and characterization of dual stimuli-responsive microcapsules with a superparamagnetic porous membrane and thermo-responsive gates, J. Membr. Sci. 321 (2008) 324-330.

[20] K. Eggers, D. Szopinski and G. A. Luinstra, Thermo-responsive microcapsules based on guar gum derivatives, Macromol. Symp. 346 (2014) 32-35.

[21] E. Loiseau, A. Q. de Boiry, F. Niedermair, G. Albrecht, P. A. Rühs and A. R. Studart, Explosive raspberries: controlled magnetically triggered bursting of microcapsules, Adv. Funct. Mater. 26 (2016) 4007-4015.

[22] A. Hamberger, A. -M. Popa, R. M. Rossi, D. R. Kattnig, D. Hinderberger, K. Landfester and D. Crespy, End-of-life indicators based on temperature switchable nanobombs, J. Mater. Chem. 22 (2012) 9909-9920.

[23] S. Xu, J. Shi, L. Yang, Q. Wu and S. Cao, Hollow PUA/PSS/Au microcapsules with interdependent near-infrared/pH/temperature multiresponsiveness, J. Appl. Polym. Sci. 133 (2016) 43008.

[24] P. Samyn and D. Stanssens, Thermal release of vegetable oils loaded in hydrophobic polymer nanoparticles, Eur. J. Lipid Sci. Technol. 118 (2016) 56-71.

[25] G. Delaittre, N. K. Guimard, and C. Barner-Kowollik, Cycloadditions in modern polymer chemistry, Accounts Chem. Res.48 (2015) 1296-1307.

[26] W. H. Heath, F. Palmieri. J. R. Adams, B. K. Long, J. Chute, T. W. Holcombe, S. Zieren, M. J. Truitt, J. L. White and C. G. Willson, Degradable cross-linkers and strippable imaging materials for step-and-flash imprint lithography, Macromolecules 41 (2008) 719-726.

[27] C. Zhao, L. Ji, H. Liu, G. Hu, S. Zhang, M. Yang and Z. Yang, Functionalized carbon nanotubes containing isocyanate groups, J. Solid State Chem. 177 (2004) 4394-4398. 
[28] T. Dispinar, R. Sanyal and A. Sanyal, A Diels-Alder/retro Diels-Alder strategy to synthesize polymers bearing maleimide side chains, J. Polym. Sci. Polym. Chem. 45 (2007) 4545-4551.

[29] E. Wisee, R. A. E. Renken, J. R. Roosma, A. R. A. Palmans and E. W. Meijer, Poly(caprolactone-co-oxo-crown ether)-based poly(urethane)urea for soft tissue engineering applications, Biomacromolecules 8 (2007) 2739-2745.

[30] C. P. Cabello, C. O. Arean, J. B. Parra, C. O. Ania, P. Rumori and G. T. Palomino, A rapid microwave-assisted synthesis of a sodium-cadmium metal-organic framework having improved performance as a CO2 adsorbent for CCS, Dalton Trans. 44 (2015) 9955-9963.

[31] C. O. Arean and M. R. Delgado, Variable-temperature FT-IR studies on the thermodynamics of carbon dioxide adsorption on a faujasite-type $\mathrm{H}-\mathrm{Y}$ zeolite, Appl. Surf. Sci. 256 (2010) 5259-5262.

[32] Y. Zhang and D. Rochefort, Characterisation and applications of microcapsules obtained by interfacial polycondensation, J. Microencapsul. 29 (2012) 636-649.

[33] W. Chen, X. Liu and D. W. Lee, Fabrication and characterization of microcapsules with polyamide-polyurea as hybrid shell, J. Mater. Sci. 47 (2012) 2040-2044.

[34] L. González, M. Kostrzewska, M. Baoguang, L. Li, J. H. Hansen, S. Hvilsted and A. L. Skov, Preparation and characterization of silicone liquid core/polymer shell microcapsules via internal phase separation, Macromol. Mater. Eng. 299 (2014) 12591267.

[35] F. Saluan, E. Devaux, S. Bourbigot and P. Rumeau, Influence of process parameters on microcapsules loaded with $\mathrm{n}$-hexadecane prepared by in situ polymerization, C. Eng. J. 155 (2009) 457-465. 
[36] M. M. Caruso, B. J. Blai6szik, H. Jin, S. R. Schelkopf, D. S. Stradley, N. R. Sottos, S. R. White and J. S. Moore, Robust, double-walled microcapsules for self-healing polymeric materials, ACS Appl. Mater. Interface. 2 (2010) 1195-1199.

[37] M. Huang and J. Yang, Facile microencapsulation of HDI for self-healing anticorrosion coatings, J. Mater. Chem. 21 (2011) 11123-11130.

[38] B. Di Credico, M. Levi and S. Turri, An efficient method for the output of new selfrepairing materials through a reactive isocyanate encapsulation, Eur. Polym. J. 9 (2013) 2467-2476.

[39] E. Querat, L. Tighzert, J. -P. Pascault and K. Dusek, Blocked isocyanate. Reaction and thermal behaviour of the toluene 2,4-diisocyanate dimer, Macromol. Mater. Eng. 242 (1996) 1-36.

[40] J. Li, A. P. Hitchcock, H. D. H. Stöver and I. Shirley, A new approach to studying microcapsule wall growth mechanisms, Macromolecules 42 (2009) 2428-2432.

[41] M. S. Romero-Cano and B. Vincent, Controlled release of 4-nitroanisole from poly(lactic acid) nanoparticles, J. Control. Release 82 (2002) 127-135.

[42] F. N. Jones, M. E. Nichols and S. P. Pappas, Organic Coatings Science and Technology, Wiley, 2017. 


\section{Figures and schemes captions}

Figure 1. ${ }^{1} \mathrm{H}$ NMR spectra of maleimide-furan adduct 6 before and after exposure to heat, regenerating the maleimide and furan components.

Figure 2a. Variable-temperature IR spectra of oxime-urethane 8 at $10{ }^{\circ} \mathrm{C}$ increments between 20 and $140{ }^{\circ} \mathrm{C}$, highlighting the appearance of an absorbance corresponding to the isocyanate moiety. Figure $\mathbf{2 b}$. An increase in intensity in the IR absorption at $2263 \mathrm{~cm}^{-1}$ corresponding to the NCO stretching vibration and a slight decrease in the IR absorbtion at $3408 \mathrm{~cm}^{-1}$ corresponding to the $\mathrm{N}-\mathrm{H}$ moiety is observed upon an increase in temperature.

Figure 3. a) Interfacial polymerisation technique used for the synthesis of microcapsules containing IPDI. b) Optical microscopic image of microcapsules M1 synthesised using a prepolymer containing a thermally-reversible Diels-Alder adduct c) Optical microscopic image of microcapsules synthesised using a prepolymer containing a thermally-reversible oxime urethane $\mathbf{M 2}$.

Figure 4. Optical microscopic images of microcapsules M1 a) at $25^{\circ} \mathrm{C}$ and b) $140{ }^{\circ} \mathrm{C}$.

c) SEM image of microcapsules $\mathbf{M} 1$ after heating to $140{ }^{\circ} \mathrm{C}$. Optical microscopic images of microcapsules $\mathbf{M} 2 \mathrm{~d}$ ) at $25^{\circ} \mathrm{C}$ and e) $150^{\circ} \mathrm{C}$. f) SEM image of microcapsules M2 after heating to $150{ }^{\circ} \mathrm{C}$. Optical microscopic images of 'control microcapsules' g) at $25^{\circ} \mathrm{C}$ and h) $140{ }^{\circ} \mathrm{C}$.

Figure 5. Stress-strain curves of PUM2 mixture and PU mixture after 24 hours at $60^{\circ} \mathrm{C}$.

Figure 6. Stress-strain curves of PUM2 before and after exposure to heat stimulus.

Scheme 1. Release of core from microcapsules achieved by depolymerisation of the microcapsule shell wall. 
Scheme 2. Synthesis of isocyanate terminated Diels-Alder prepolymer 7 i) furan, toluene ii) 3-amino-1-propanol, $\mathrm{MeOH}$ iii) toluene reflux iv) furfuryl alchol, toluene v) TDI, THF.

Scheme 3. i) TBDMSCI, Et ${ }_{3} \mathrm{~N}, \mathrm{CH}_{2} \mathrm{Cl}_{2}$ ii) $\mathrm{HO}-\mathrm{NH}_{3} \mathrm{Cl}, \mathrm{Et}_{3} \mathrm{~N}, \mathrm{EtOH}$ iii) TMXDI, THF iv) TBAF, THF v) TDI, THF. 
Figures and Schemes

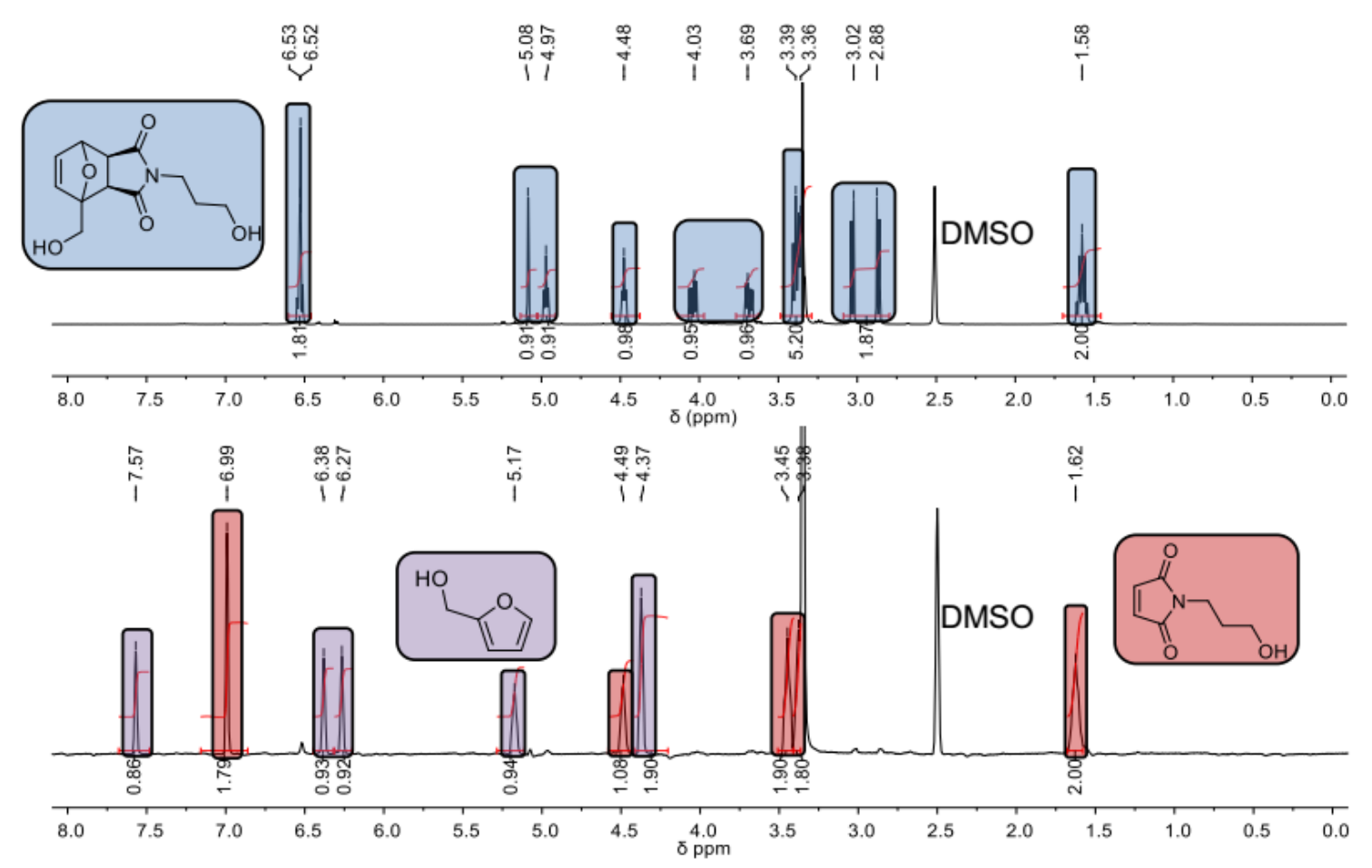

Figure 1

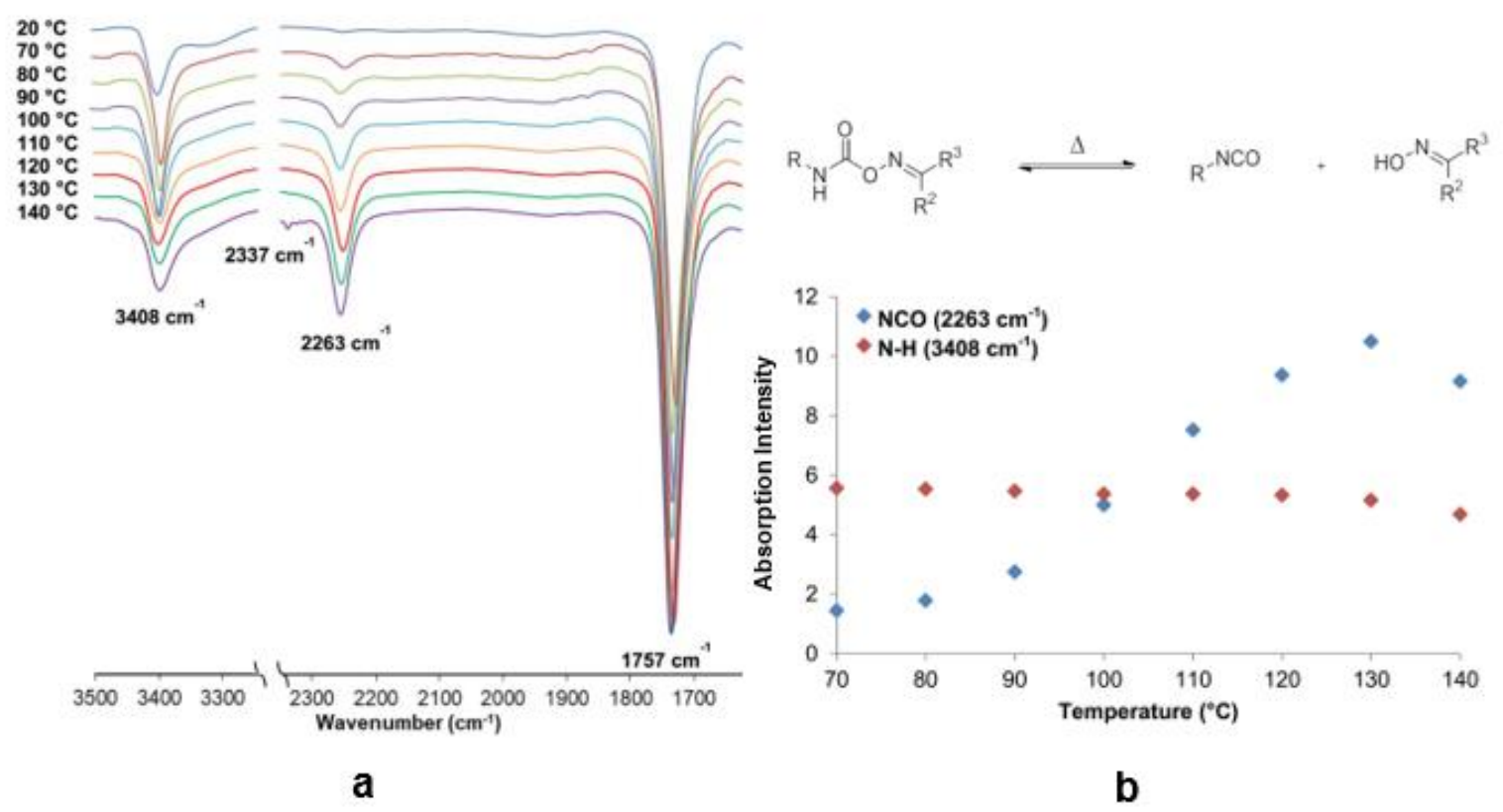

Figure 2 


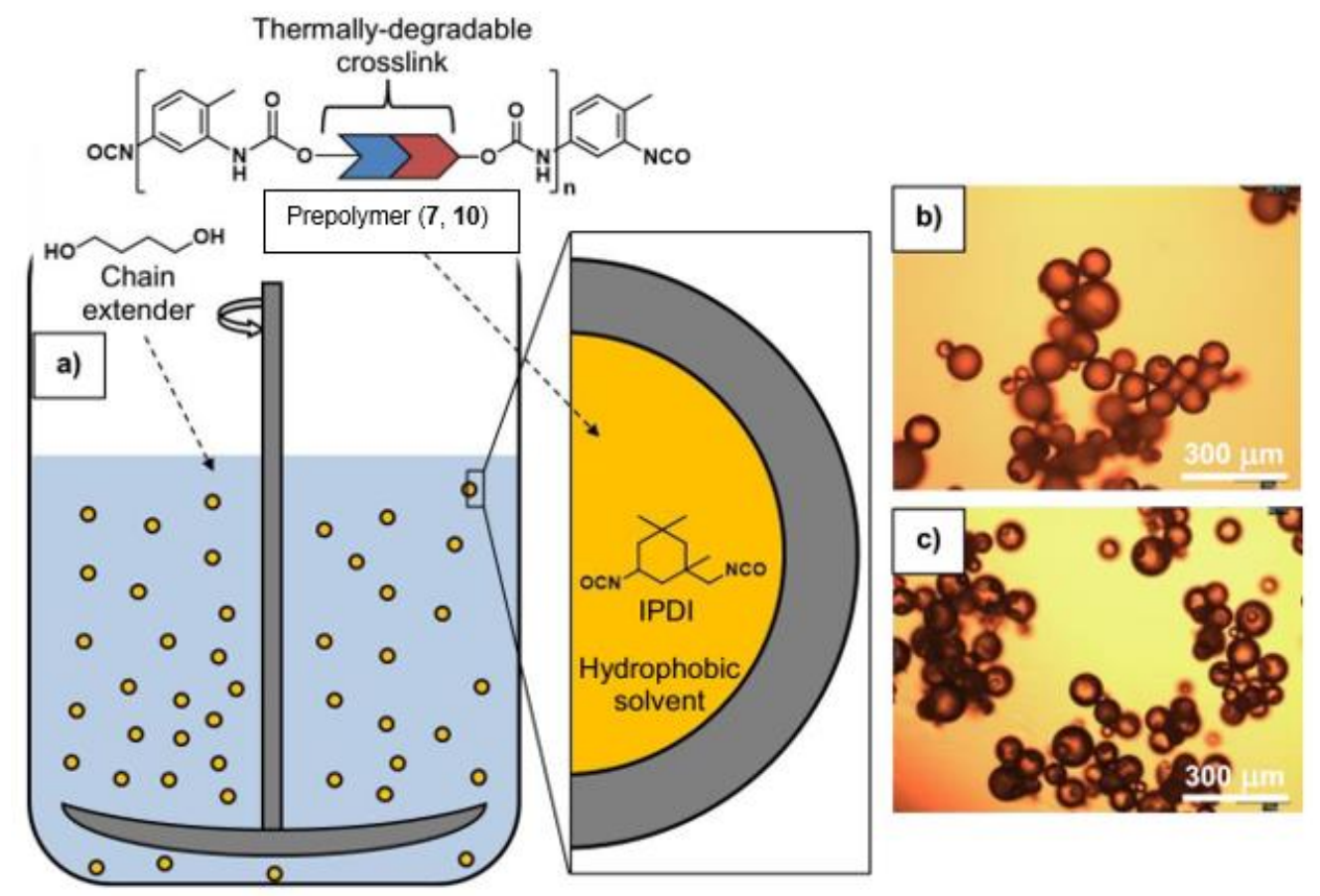

Figure 3

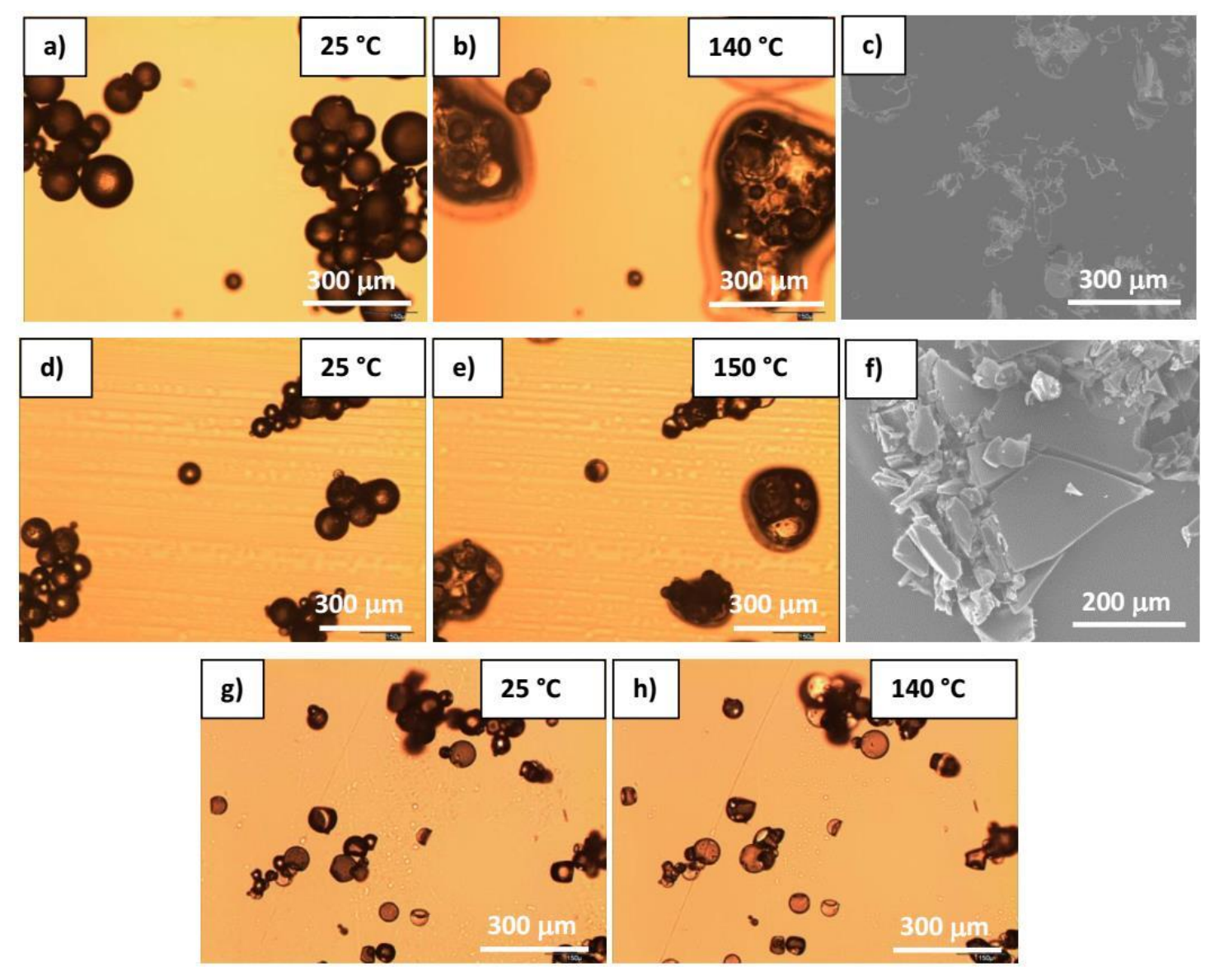

Figure 4 


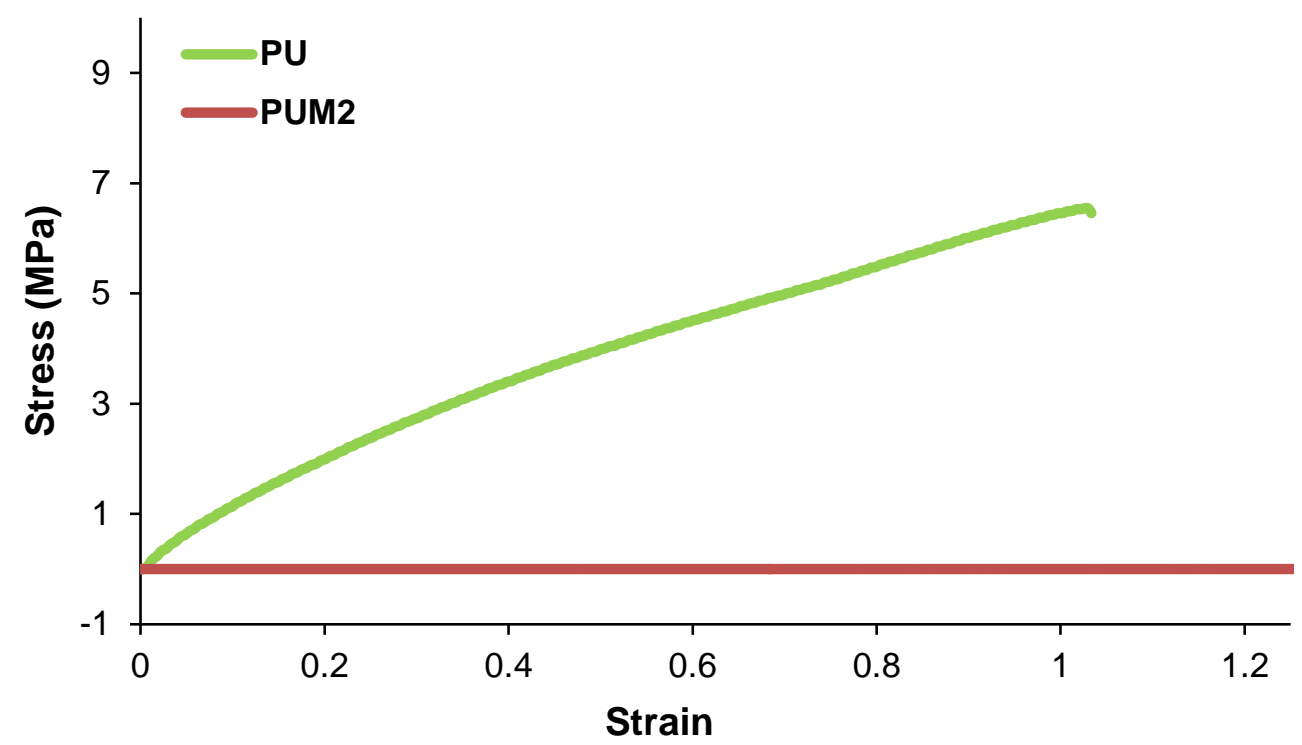

Figure 5

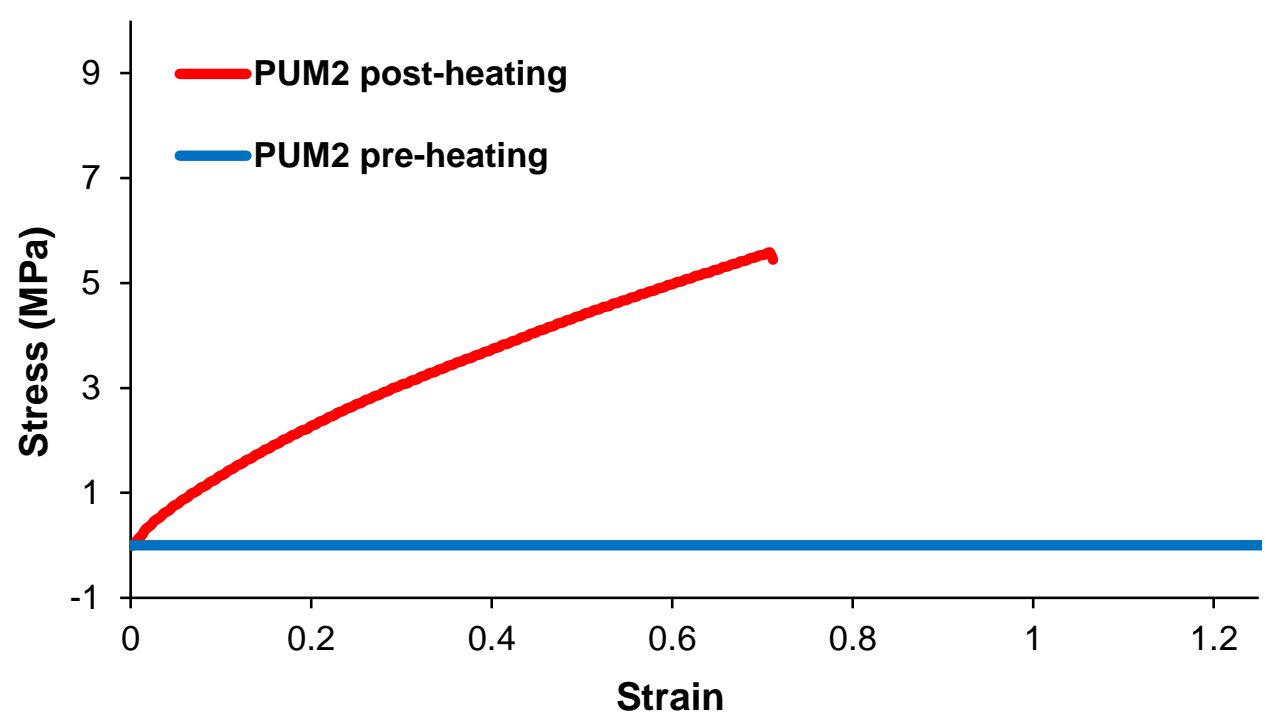

Figure 6

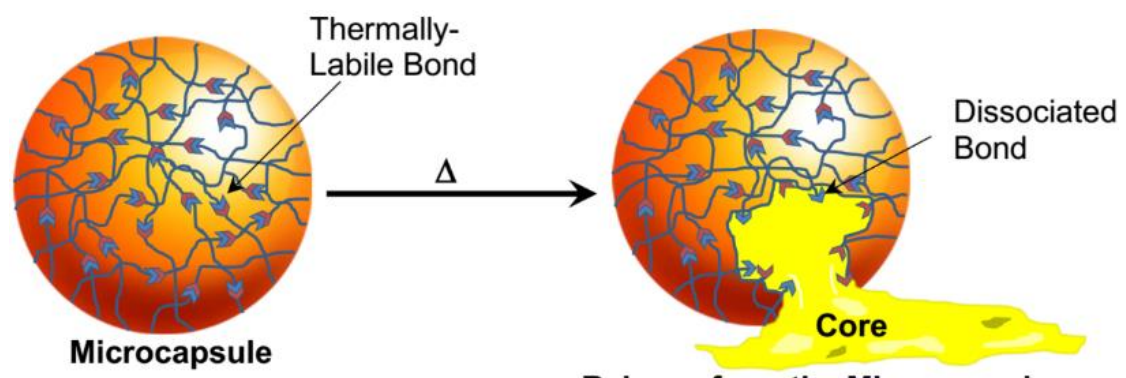

Release from the Microcapsule

Scheme 1 


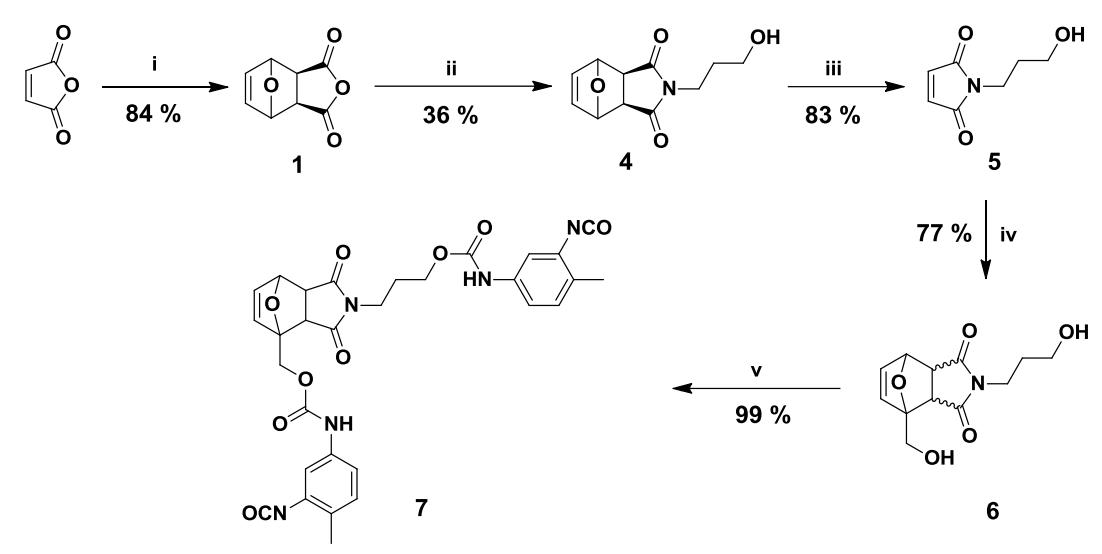

Scheme 2

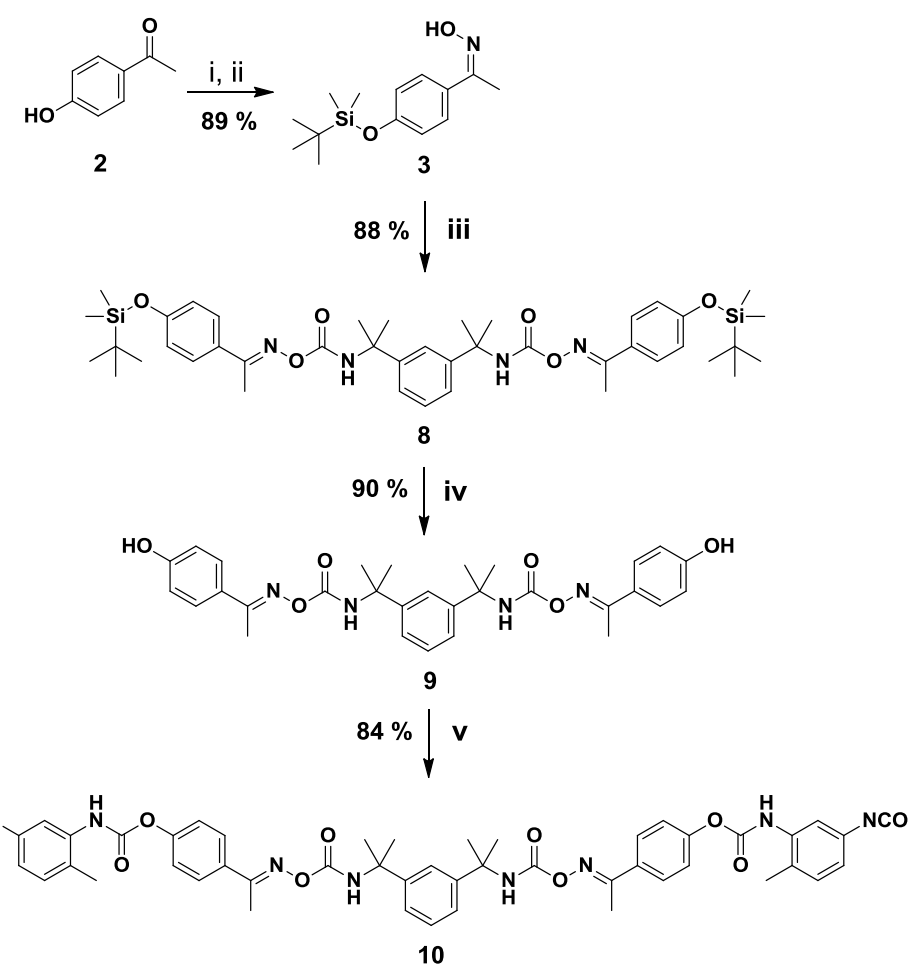

Scheme 3 